\title{
Cyber Literature as an Alternative for Sidoarjo Woman Writers Community: A Sociological Perspective in Literature
}

\author{
Niko Fediyanto, \\ Vidya Mandarani, \\ Yuli Astutik \\ Universitas Muhammadiyah Sidoarjo, Jl. Mojopahit 666B Sidoarjo, \\ Indonesia \\ nikofediyanto@,umsida.ac.id
}

Article History: Submitted on $25^{\text {th }}$ April 2021; Accepted on $8^{\text {th }}$ June 2021;

Published on $30^{\text {th }}$ June 2021

\begin{abstract}
The development of the globalization information system and the effects of the global pandemic almost demands almost everyone to optimize technology in response to various problems, including literature and writing. This article presents cyber literature as an alternative for the development of Pena Perajut Aksara, a women writers community in Sidoarjo. The problems studied were how the pattern of writing strategies for this community and how the community responds to cyber literature development as an alternative writing strategy. To answer the problems raised, researchers used a qualitative descriptive method. Theoretically, the researcher applied Pierre Bourdieu's perspective on the Field of Cultural Production. The data collected by using the unstructured interview method. The results of this study indicate that as the main strategy, this community relies on the curation of authors who have been consecrated as curators. Meanwhile, the development of electronic/cyber-literature has also begun to be taken seriously as a strategy to achieve consecration for this community. As an impact of research limitations on descriptive patterns, this study's results suggest more comprehensive and multi-disciplinary research to provide more concrete and measurable recommendations for the community in achieving consecration and broader public recognition in the future.
\end{abstract}

Keywords: cyber-literature, writers' community, consecration 


\section{INTRODUCTION}

The development of human civilization and its effect on the rapid growth of technology makes significant changes in many aspects of life. Fine arts is one aspect that constantly changes according to the dynamics of civilization. Tales are assumed to have been told before humans knew writing. Literature has become something that remains, even though the medium varies from oral, paper, and electronic media. However, every change may have specific effects as literature cannot be separated from the convention.

This paper discusses the Sidoarjo female writer community's strategy in getting the public's acknowledgment and their perception of cyber-literature as an alternative medium to achieve public recognition. The public's need for the internet and the fading of publishing on paper brought the emergence of cyber-literature or electronic-literature. The Sidoarjo women writers community has published two anthologies of their short stories conventionally, namely by publishing printed books. This does not go along with readers' tendency to prefer reading using digital platforms instead of printed books.

strategy of publishing works using the print platform seems to indicate a problem being discussed in this article. This is because the facts show that the buying interest in print media (including books) has decreased significantly so that it can be assumed that the strategy adopted by this community is problematic.

Although there has not been specific research determining the number of printed books reading decline, the threat of the fall of printed books as reading material can still be assumed. The facts show that in recent times, business related to printed books has decreased significantly. Liputan6(Situmorang, 2020) reported a decrease of 80 percent $n$ interest in buying books due to at least two factors: first, readers' preference to choose readings accessed via electronic devices gadgets. Second, this decline is related to the Covid-19 pandemic. Meanwhile, Kontan Daily (Nugroho, 2020) wrote that the decline in book sales is de. This condition is exacerbated by the practice of pirating works on the internet.

Cyber platforms, especially in Indonesia, have made significant changes in terms of recognition given by the public. Several pieces of research had discussed the development of cyber-literature in Indonesia. Nurhidayah (Nurhidayah \& Setiawan, 2019) explained the journey of cyber-literature and its relation to post-modernism and popular literature comprehensively. She explained the contestation between noble literature and popular literature and underlined that the development of literature influenced by the internet's domination has recently made market tastes very dominant in writers' contestation on the literary stage.

From the perspective of sociology, literature is an arena of cultural production dominated by elitists. The writers with minimal capital use various 
strategies to win the competition because curation on arts is not entirely the critics' but also the market.

Researchers have shown that electronic-based literature (commonly known as cyber-literature has been a phenomenon that needs to be discussed. Several writers even showed the benefits of cyber-literature. The trend to discuss cyber-literature, however, is increasing in the past two years. This is even more relevant due to the pandemic Covid-19 condition because the need for cyber platform reading should be increasing. In 2019 (Octoveria et al., 2019) discussed the cyber-literature phenomenon on Instagram to cultural phenomena on Instagram in Indonesia in 2018-2019. More specifically, they discussed Instagram as the zeitgeist of cyber literature and Nanti Kita Cerita dari Hari Ini (NKCTHI), representing the zeitgeist of cyber literature on Instagram. This study indicates that cyber literature does not erase the existence of traditional literature in printed form. On the other hand, NKCTHI on Instagram as a representation of cyber literature complements existing traditional literature.

A study by (Cinthya \& Wati, 2020) focused on the phenomenon of cyber-literature in Islamic religious literature related to the emergence of literary works with Islamic content uploaded by their authors through internet sites, blogs, applications, and other social media networks. This qualitative research describes the trend of Islamic religious cyber-literature in Indonesia and the motives of the authors. The study shows that the ease of publishing is the main attraction of cyber platforms for Islamic literature writers.

Several studies refer to the Wattpad platform as a concrete form of cyber-literature and its relationship with authors and readers, namely the study by (Muslimin, 2016), which studied Wattpad as an alternative for writers and readers, and (Yoesoef, 2019), which discussed Wattpad and Webnovel as generation $Z$ reading. Meanwhile, two other studies that specifically discussed the sociology of literature were the studies by (Kardiansyah, 2019) and (Ayub, 2020). Each of these studies discussed Wattpad as a story-sharing website from the perspective of the field of literary production and Wattpad as a writing platform for the writers' community.

The studies mentioned in the previous paragraph show that the discussion of cyber-literature has been carried out in a broad scope. Several points of view are also used in analyzing this phenomenon. However, there is no study that discusses the community of writers on a small scale or writers who do not have legitimacy. In fact, studies on non-legitimate authors are significant because cyber-literature has the potential to open wider opportunities for author competition to achieve legitimacy.

The researcher considers that this study is crucial to carry out as a continuation of the studies on writers/ writers' community in search of legitimacy. This is to offer positioning and a range of possible strategies for them to compete with other writers in Indonesia. This research is projected into the questions of what strategy the Sidoarjo women writers community 
has applied and how they perceive the cyber-literature phenomenon as a new emerging platform in literary products publishing. The researcher affirms the results of previous studies and uses these findings as references in this study. This is important as a basis for considering the position and recommending strategies for writers in the women's writing community in Sidoarjo.

Pierre Bourdieu's sociological perspective on The Field of Cultural Production is used in this paper because the concept is representative to describe the strategies used by the community. (Bourdieu, 1993) described the 'field' as a network in which actors (agents) are positioned according to capital (a recognition) and, at the same time, by this particular capital distribution structure. The strategies adopted depend on their strengths and shape in each agency's position according to their relationship with (dominant) power.

\section{METHOD}

This research applied a qualitative approach in finding answers to the problems posed in this study. A qualitative framework means that the total method does not focus on size, intensive data, or the frequency that ultimately processes to get meaning according to the context (Denzin \& Lincoln, 2005). The reality that is built into social life is studied, studied qualitatively.

The researcher used an unstructured interview to collect the data because an open interview provides more space for the resource person to explain. This tactile interview model has advantages in the cultural context of a society that lives as a philosophy that is in constant motion. The substance is that the informants' descriptions also function as heuristic tools for the next meaning to answer the questions in this study.

The perspective used in this research is sociological, which views literature as an inseparable part of the outside world. Specifically, the concept applied in this research is about the Field of Cultural Production by Pierre Bourdieu.

In general, the steps taken by the analysis researcher are as follows.

a. The data obtained and classified is used as material to find a strategy used by the authors in the community to determine the strategy used. One of the keys in an arena, according to (Webb et al., 2002), is the existence of a process of legitimacy/judgment.

b. To answer the challenge of this community's perception of cyberliterature development, the researchers explored the data through open interview questions. The results of these interviews were used as a basis for determining their position in the Field of Cultural Production associated with cyber-literature development. 


\section{FINDINGS AND DISCUSSION}

To provide clear direction in the discussion, the researcher has divided the discussion into several sessions in this study. First, the researcher discusses the writing community's strategies to gain legitimacy in the world of writing. This section describes the current condition so that researchers can see this community's position in the Field of Cultural Production. Second, the researcher discusses the community's perception of the development of cyber-literature. Finally, the researcher will continue with the discussion of these results to obtain recommendations from this study's results.

\section{a. Strategies to Gain Legitimacy}

This study indicates that the world of writing in a relatively small scope, such as Sidoarjo, cannot be separated from domination and legitimacy. Although there is no economic motive that underlies the decision to become a writer for each community member, they still carry out a strategy that can penetrate the Field of Cultural Production. This community realizes that they are still in the category of writers who have not been legitimized in the large field of Indonesian literature.

The cultural production field in Sidoarjo is different from a city that has a tradition of a massive writing competition, such as Yogyakarta, as found by (Salam \& Anwar, 2015). This writer's community does not directly face the domination of structured legitimating givers such as the great writer's community, educational institutions, or government agencies that have legitimacy in literature.

Based on the data collected by researchers, this community stated that the purpose of building this community is a forum/community that was founded only because of the same mission. Even though the members of this community come from different backgrounds (which also allows them to have diverse socioeconomic backgrounds), they have the same problem, namely the stagnation of creativity.

Pena Perajut Akasara community consists of 19 writers who are not full-time writers. Its members come from various backgrounds ranging from housewives to entrepreneurs. Researchers do not get exact data on the date of the founding of this community, but their seriousness to become a community of writers has been around for at least the last four years.

This community has produced two anthology books for short stories. First, they published an anthology entitled Bunga Kehidupan in 2019. After one year, they again published an anthology entitled Analektika Jelita. Both anthologies contain 17 and 14 short stories, respectively. 
The motive behind this community's formation shows that they wrote as an expressive activity, arts for art's sake. However, it also cannot be ignored that such patterns are a reflection of the domination and domination of females in the social structure, especially with regard to authorship.

The genre chosen by writers in this community is popular writing. This is only natural if you look at the background of the writers of this community. As mentioned in the previous paragraph, the authors do not have an economic motive so that they can be classified in the class (both socially and economically). The writings they write also reflect their personal lives or their lives, so it can be assumed that their target audience is also from the middle class.

Another feature of identical works to the middle class is the lack (or even absence) of the intention to include political aspects, as mentioned. Most of the works they write even feature the "Islamic chic" (a term coined by Ariel Heriyanto). K.Y. Karnanta (Karnanta, 2017) It is stated that the authors in this category are often squeezed between the consecration by artistic curators and market recognition as measured from an economic point of view.

Table 1:

Literature Field in Contemporary Indonesian Literature Space

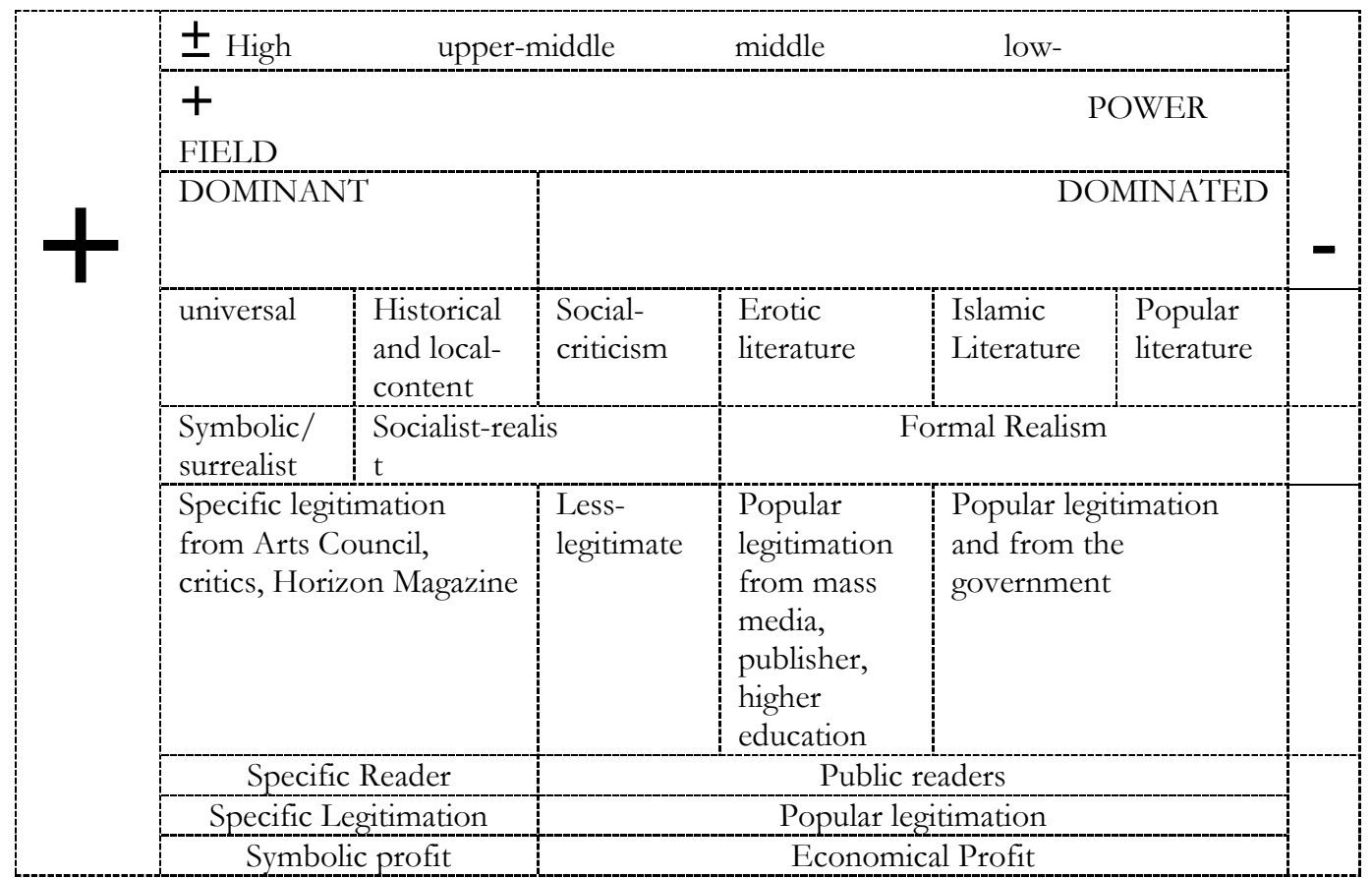

Source: K.Y. Karnanta (Karnanta, 2017) 
Referring to the Field of Literature in Contemporary Indonesian Literature according to Figure 1, these writers are popular and Islamic writers. Thus, the legitimacy needed is from readers, mass media, government, and the market.

On the other hand, the community is fully aware that they need a strategy to stay in authorship. When the authors carry out the writing process, they are bound to a procedure that requires the brand to go through the curation stage by the author who has consecrated/has legitimacy. In this process, all processes from writing to curation are carried out by writers who have better legitimacy in Indonesia's field of literature. In accordance with the data obtained, this legitimate female writer must also curate writings from several other communities, which are also writers' communities.

In addition to conducting a curation system involving legitimate author curators, this community also makes a number of other efforts to improve the quality of writing, such as regular meetings, discussions, and forums that involve practitioners or academics. The meetings they previously held were held on a monthly basis, but in the past year, they have not been able to hold these meetings regularly due to pandemic-related restrictions. Discussions are still being carried out even though they are online.

\section{b. Cyber-literature as A Strategy}

According to Endraswara's definition (Endraswara, 2006), cyber-literature does not refer to certain definitional restrictions but rather literary activities that utilize computer or internet media. The term Cyber, literally, only serves as a description of other words, such as cybernetics, cyberspace, or cyber transactions. This definition refers to the movement of platforms from print to digital, from physical distribution to internet distribution.

(Fitriani, 2007) pointed out that cyber-literature emerged in the early 2000s with online mailing lists, one of which is the poet mailing list. In the following years, new types emerged, such as mailing list literature, portal literature, and blog literature. The emergence of cyber-literature gave rise to a new phenomenon, namely the emergence of novice writers, who previously had no place in literature because they were not close to influential critics / literary communities.

Endraswara in (Fitriani, 2007) describes some of the writers' motivations when entering the world of cyber-literature. First, an author is looking for new creativity and considers cyber-literature as an interesting new field. They want to find a means to channel their creativity without being constrained by legitimacy. Second, an author wants to achieve popularity more easily and cheaply quickly. Cyberliterature allows them to achieve worldwide distribution without 
going through many obstacles such as critics, art curators, or expensive conventional distribution systems. Third, Some writers use cyber-literature as mere land for playing the internet and want to escape from the prison for newspaper literature. They think that newspaper and book literature is too restraining and hegemonic.

This definition was then given in the form of the interview. When asked questions about the possibility of publishing online, this community assumes that they are currently still publishing in the form of printed books but does not rule out the possibility of going towards online books. They admit that there are distribution problems that might occur when there is a package when the buyer is out of town and problems with printing costs and others. However, they still face obstacles regarding the low understanding of online publishing.

When asked about the prospects for cyber-literature, the community did not argue that this would be necessary for the future. Some of the community personnel have even started to develop an online magazine called Nefertiti.

Regarding the development of writing skills, this community learns online both in terms of writing material and when editing and consulting about our writing drafts via email, WhatsApp, and others.

The community also uses social media, which is a 30-day challenge to write on Facebook and provide comments to each other on the results of writing. This is very helpful for community members in learning to write and as a medium for community members' expression. By doing a 30-day challenge to write on social media, the community is increasingly known in the Sidoarjo area and other areas. This is evident from the increase in community members who will participate in the next work writing. Community members also regularly fill out a rubric in the online magazine Nefertiti to develop online writing techniques because there are so many rubrics featured in the online magazine Nefertiti.

Community members will have an obligation to use cyberliterature because they have to keep up with technological developments to be accepted by readers and exist in the world of literacy. The cyber pattern will certainly have a positive impact because it can help facilitate the writing process and the writing publication process.

\section{c. Discussion}

Based on the data and the results of the analysis on the findings in the previous section, it can be said that the Pena Perajut Aksara community understands their position as writers in the arena of cultural production in the Cultural Production Field of 
Contemporary Indonesian Literature. In accordance with the research results of K.Y. Karnanta(Karnanta, 2017), the written forms they publish are of popular genres with a tendency to include elements of popular, motivational-psychological, and Islamic elements. They also have a publishing strategy that takes advantage of legitimate authors. However, the findings that do not fit the category made (Karnanta, 2017) is that this community has no economic motive.

The findings of this research are inconsistent with the research conducted by (Merawati \& Suwartini, 2018), which stated that cyber-literature is a form of rejection of literary canon. This study shows that these communities still recognize canonicity, but they prefer a more moderate strategy by using legitimate authors as a trajectory towards the consecration.

In terms of strategies to improve writing skills, this community has the same strategy as typical mentioned by Nilofar(Nilofar, 2020) based on the results of research conducted at Komuntas Pelangi Sastra Malang (PSM). The activities carried out by the community are literary activities, such as literacy gatherings, literary discussions, book reviews, reading poetry, publishing anthologies of short stories and poetry. In relation to literary development, the Women's Writers Community has referred to cyber-literature as an open attitude to accept changes. This result is in line with the recommendation of research by Nurhidayah \& Setiawan(Nurhidayah \& Setiawan, 2019), which states that literature is suitable for use by novice writers. This category of beginner writers is obtained by referring to the classification of writers in Karnanta(Karnanta, 2017), which describes the position of beginner writers with the genre as it is now.

\section{CONCLUSION}

This study shows that the Pena Perajut Aksara Community is in the classification of writers with popular literary genres. Writers at this level tend to need legitimacy from the legitimate giver to get consecration. The strategy used is to get curation from writers who have been consecrated in popular literature publishing. However, according to the classification of Contemporary Indonesian literature, steps are needed so that they can gain legitimacy in the Field of Cultural Production.

Regarding the development of cyber literature in Indonesian Literature, this community has made good efforts by optimizing social media. Several studies(Muslimin, 2016)(Yoesoef, 2019)(Kardiansyah, 2019) have shown that Wattpad media have better reach and relations with readers, but this is not sure to apply to this community. 
Some of the recommended steps are as follows. First, writers can improve their writing skills with social/political criticism for content. Writing in non-popular genres can broaden the reach of readers, increasing legitimacy. Second, communities need stronger reach and networks to gain better legitimacy. This can be done by making networks with other writers' communities or with legitimate media. Third, the community needs to make more massive efforts related to the publication of internet / cyber-based literary works.

Meanwhile, the suggestion for future researchers is that this research yields several points, but the approach taken can still be optimized.

In order to gain broader and better legitimacy, these communities need to develop their writing style. This community needs to come up with ideas about the production of works that refer to social/political criticism. This was done to get them closer to the acknowledgment in literary curation. As the problem raised, this research has a number of points recommended to the following Sidoarjo Women Writers community.

\section{REFERENCES}

Ayub, N. S. (2020). Wattpad as a Platform for Writing Community: A Conceptual Framework. June, 149-153.

Bourdieu, P. (1993). The field of Cultural Production. Columbia University Press.

Cinthya, N., \& Wati, R. (2020). Fenomena Sastra Cyber: Trend Baru Sastra Islami Dalam Masyarakat Modern Di Indonesia. Jurnal Edukasi Khatulistiwa, 3(1), 1. https://doi.org/10.26418/ekha.v3i1.37991

Denzin, N. K., \& Lincoln, Y. S. (2005). The Sage Handbook of Qualitative Research (3rd Edition). In N. K. Denzin \& Y. S. Lincoln (Eds.), The Sage Handbook of Qualitative Research (Third). Sage Publication Inc. https:/ / doi.org/10.4324/9780203409527

Endraswara, S. (2006). Metodologi Penelitian Sastra, Epistemologi, Model, Teori dan Aplikasi. Pustaka Widyatama.

Fitriani, L. (2007). Sastra Cyber Di Indonesia. LINGUA: Jurnal Ilmu Bahasa Dan Sastra, 2(2), 66-74. https://doi.org/10.18860/ling.v2i2.567

Kardiansyah, M. Y. (2019). Wattpad as a Story Sharing Website; Is it a field of literary production? ELLiC Proceedings, 3, 419-426.

Karnanta, K. Y. (2017). Hierarki Sastra Populer Dalam Arena Sastra Indonesia Kontemporer. JENTER A: Jurnal Kajian Sastra, 4(1). https://doi.org/10.26499/jentera.v4i1.379

Merawati, F., \& Suwartini, I. (2018). The Discourse of Cyber Literature in Indonesia. In R. R. Kundharu Saddhono, Muhammad Rohmadi' (Ed.), Workshop on Language, Literature and Society for Education (pp. 1-7). EUDL. https://doi.org/10.4108/eai.21-12-2018.2282796

Muslimin, M. F. (2016). Literasi Siber: Wattpad Wahana Alternatif Penulis 
Dan Pembaca. Prosiding Seminar Nasional "Budaya Literasi Menuju

Generasi Emas BagiGuru Pembelajar," Desember 2016, 148-152.

Nilofar, N. (2020). Arena Produksi Kultural Komunitas Pelangi Sastra

Malang. Alayasastra. https://doi.org/10.36567/aly.v16i1.498

Nugroho, S. (2020). Masa Depan Industri Penerbitan. Kontan.Co.Id. https://analisis.kontan.co.id/news/masa-depan-industri-penerbitan

Nurhidayah, S., \& Setiawan, R. (2019). Lanskap Siber Sastra:

Postmodernisme, Sastra Populer, Dan Interaktivitas. Poetika, 7(2), 136. https://doi.org/10.22146/poetika.v7i2.50779

Octoveria, E. N., Femigasari, N., \& Athali, N. (2019). Capturing Zeitgeist on Cyber Literature: a Case of @Nkcthi on Instagram. Poetika, 7(2), 158. https://doi.org/10.22146/poetika.v7i2.51207

Salam, A., \& Anwar, S. (2015). STRATEGI DAN LEGITIMASI KOMUNITAS SASTRA DI YOGYAKARTA: KAJIAN SOSIOLOGI SASTRA PIERRE BOURDIEU. Widyaparwa, 43 No.1, 25-38.

https://www.widyaparwa.com/index.php/widyaparwa/issue/view/11

Situmorang, A. P. (2020). Terkapar, Pendapatan Penerbit Buku Anjlok 80 Persen selama Pandemi. Liputan6.Com.

https://www.liputan6.com/bisnis/read/4349808/terkaparpendapatan-penerbit-buku-anjlok-80-persen-selama-pandemi

Webb, J., Schirato, T., \& Danaher, G. (2002). Understanding Bourdieu (Series: Cultural Studies). Allen\& Unwin, 227.

Yoesoef, M. (2019). Cyber Literature: Wattpad and Webnovel as Generation Z Reading in the Digital World. Proceedings of the International University Symposium on Humanities and Arts (INUSHARTS 2019) Cyber, 453(Inusharts 2019), 128-131.

https://doi.org/10.2991/assehr.k.200729.025 